\title{
The Development of English Textbook Based on Problem-Based Learning for Junior High School Class VII as the Implementation of Curriculum 2013
}

\author{
Elmiati, Suharni, and Yelliza \\ English Department of STKIP PGRI West Sumatra \\ Padang, Indonesia \\ elmiatisofiana@yahoo.com, nenikuchi@ymail.com, and Yellizajr.@gmail.com
}

\begin{abstract}
The purpose of this research was developing of English textbook of Problem Based Learning for Junior High School Class VII as the implementation of Curriculum 2013. This research was the continuation of the previous research about evaluation of English Textbook Entitled When English Rings the Bell for Junior High School class VII as the Implementation of Curriculum 2013. However, in this research, the researchers develop English textbook based on the criteria of good textbook according to the experts. Besides, they also see the conformity of the content from the textbook. So, from this they will know how far the effective of the text book for the user (teachers and students). The design of this research was developmental research. The approach was using 4D model. They are Define step, Design step, Develop step, and Disseminate step. The first year was began by Define. Here, the researchers analyze the textbook, it includes teachers' need analysis, students' need analysis, and literatures review, and then it will be focused on designing the textbook. Based on the primary research that has been done by the researchers on schools in Padang, especially on Piloting Schools as the implementation of Curriculum 2013, the findings showed that from students' and teachers' need analysis, the teachers and students need English textbook of Problem Based Learning for Junior High School class VII as the implementation of Curriculum 2013. So far the text book is still far from Problem Based Learning.
\end{abstract}

Keywords; Development, English textbook, Problem Based Learning, Implementation Curriculum 2013

\section{INTRODUCTION}

English is the language used to communicate both oral and written in all over the world. The ability to use English language in communication is very important. Furthermore, the Indonesian government, The Ministry of Education and Culture, has required students to learn English from class VII at Junior High School. It is widely known that the implementation of this policy has already begun for ages but the results showed that there was no effect on the student's ability to use English neither orally nor written in everyday life. The questions need to be answered; "What are the causes of this problem occur?" Researchers strongly assume that this problem occur for several reasons. First, the students are lack of motivation to learn English. Second, students do not use the appropriate learning strategy in learning English. Third, teachers do not use the proper technique when teaching English in the classroom. Fourth, books that become a source of learning English used are not relevant to the students' need. Fifth, the curriculum does not concern on some crucial aspects such as learners language development, world demand and the needs of learners.

The government is really aware that the results of learning of English in schools cannot be achieved optimally. Consequently, the government design some policies related to education in order to achieve the learning targets. One of the policies, The Ministry of Education and Culture designed recently, is English language-based approach curriculum which is more attention both oral and written text that can be used in everyday life. Referring to the curriculum improvement policy, the government, especially the Ministry of Education and Culture has set the new curriculum in accordance with the stipulation of Permendikbud No. 68 th 2013 about Basic Comptentence (KD) and Junior High School Curriculum Structure and Islamic School. English textbook is an important element in the implementation of teaching and learning whether it is in the classroom or outside the classroom. In addition, for the teachers, it can really give benefit because teachers can make a plan about learning activities based on that book that will be used inside and outside the classroom after classes.

In evaluating or reviewing the contents of a book, there are a few things to note. The first aspect is the design and organization of the presentation of the book. It is related to the display of images and the organization or arrangement of the material in the book. The second aspect is the content of the book. For more details we should read the topic, texts, exercises presented in the book. The third aspect is language contain in the book. In this case, we can review the appropriateness of the language with aspects of language skills to be developed and achieved by students as learners such as in listening, speaking, reading and writing skill. Those aspects will be evaluated based on the Curriculum 2013. 


\section{A. Definition of Textbooks}

Teaching and learning activities are complex activity. It occurs because there is interaction between teachers, students and teaching materials in order to improve knowledge of students. Learning activities can work well if there is a good guide for teachers and students. The textbook is a guide used for teachers and students to prepare them to participate in learning process. Teachers need textbooks to prepare themselves before presenting the subject matter inside and outside the classroom. Textbooks are books that created and compiled systematically by the experts [1]. This means that text book is a book designed and prepared by the experts for a particular purpose. Experts must pay attention to the principles of good books so that when teachers and students using this book it can help them understand the material well.

Textbooks are material written with a logical arrangement consisting of a topic and the teaching materials to be used at a certain level [2]. It can be explained that the textbook is a book that consists of topic and other teaching materials used in a particular class. Furthermore, textbook is something that is most closely related to the teachers and students as the user [3]. It can be concluded that the book has an important functions for teachers and students. Teachers and students need a book to make the learning process. The book is an element that plays an important role in conducting learning activities. It can be concluded that the textbooks are media that support the implementation of the learning process to achieve the better results.

\section{B. Principles of Good Textbook}

In order to achieve better learning outcomes, the teacher must choose and consider the textbooks used, so that students can understand the material in the book easily.

The contents of textbooks should be in accordance with the demands curriculum and syllabus and materials tested in the semester exams and the National exam, because the contents of test should be appropriate with curriculum and syllabus.

Furthermore, six criteria that should be in a good book, there are:

a. Textbooks should contain information in how using the book, items and skills presented.

b. Textbooks must mention the media used in accordance with aspects of the language used.

c. Textbooks should contain a situation and a significant topic in the book.

d. Textbooks should emphasize the differences in purpose and language skills to be achieved from the group of words that are on the books. There are many kinds of the same words which has a different meaning.

e. Textbooks should provide initial guidance on any reading text in the book.

f. Textbooks should display image, diagram and appropriate table [3]
Furthermore, the criteria of a good book for students. He explains the criteria of the text book as follows:

a. Students need to study the book.

b. Learning atmosphere create the physical comfort, freedom of expression, and differences

c. Students acquire the learning objectives of the learning experience conducted.

d. Students actively participate in the learning process.

e. The learning process associated with the daily activities of students and as learning experience for them.

f. The learning process is a learning experience for students [4]

\section{Principles Good Material in Textbooks}

Learning activities may not run properly without the support of some elements such as teachers, students, media and subject matter. These elements cannot be separated from one another. They have a close relationship each other. One of the most important elements in implementing the learning activities is a textbook. Most of teachers choose textbooks as primary reference material in the search for learning material. Teaching material is a systematic overview of techniques and exercises that will be used in the classroom [5]. The teaching materials consist of information, equipment and text that will be implemented inside and outside classroom.

Researchers chose the curriculum because the curriculum has been created and designed by many experts. Of course curriculum that meets the criteria of good teaching and learning process. Researchers also believe that this discussion is based on the analysis of the experiment (intellectual, communicative) and the reconstruction social (social behavior). So researchers can check the relevance of the material in each unit of the textbook with the curriculum used is the School-Based Curriculum.

\section{Criteria of Development Evaluation on Textbook}

Textbook is an important source in the process of teaching and learning. Therefore it is important for us to evaluate it so that effective teaching and learning process is accomplished in the classroom. Evaluating the textbook is an assessment of things contained in these textbooks, whether students like to do the exercises in the book or the teachers can use it easily. There are some things that should be considered in evaluating textbook, that are:

a. Background author of the material.

b. The accuracy of the material in the textbook curriculum, whether the material is matched with curriculum and syllabus in general.

c. Physical form of textbook

d. Characteristics of logistics [5]

It concerns the price, the key answers that can help students in explaining the material and planning 
In this study, researchers only focus on two aspects above. The first is the appropriateness of teaching materials with the curriculum used. While the latter is elderly physic form of textbooks, it is very important to users of these textbooks, teachers and students.

On the other hand, Worth also expresses about evaluating textbooks. That is the goal and the approach, design and composition, the content of the language, topic, methodology, and effectiveness aspects of the book. Cunning Worth explained several questions in evaluating textbooks:

1. Aims and Textbook Approach:

a. Is the target of text book appropriate to the aim of teaching?

b. Is it flexible? Is the text book can be used tovarious learning styles?

c. Does it match to the teaching and learning situation?

d. Does textbook cover all or in part of what is needed? Is a good source for teachers and students?

2. Design and List of contents of textbooks

a. Does the content arrange sequentially?

b. Is it organized?

c. Are the students' assignments well-organized?

d. Is there a link between students' assignment with student activity?

e. Are the materials suitable to the students?

f. Are there any interesting pictures and illustrations?

g. Is the material clear?

h. Are the assessment and progress of textbook material suitable for students? Is that progress allowed them to complete the task?

3. Language Content of Textbook

a. Does the textbook contain material about the pronunciation task?

b. Does the text book arrange in orderly language conventions?

c. Do style and precision matched of a social situation?

d. Does the material in accordance with the student's vocabulary?

e. Does the textbook include grammar correspond to the level of instruction and in accordance with the needs of students?

4. Skill in Textbook

a. Do the listening materials recorded well regarding with the background of information, questions, and activities which is useful for students' understanding?

b. Is the material to talk available?

c. Is the reading material brought out well?

d. Is the writing material displayed properly and followed with a good construction?

e. Topics in the Textbook

1) Is the topic various?
2. Is the material attractive for students? [6]

\section{E. Problem-based Learning}

Problem-based learning is part of a scientific approach. Problem-based learning is started from problems or certain issues to be solved. Based on the regulations of the Minister of Education and Culture No. 65 Year 2013 concerning the standard process Elementary and Secondary education, project-based learning is learning that produce work based problem. The background of implementing project based learning is the requirement of skills that must be mastered by learners in the learning process. The process is observing, asking, trying, reasoning, performing and creating.

Then, the Objectives and results of problem-based learning models are:

1. Thinking skills and problem-solving skills. Learning is aimed at developing higher-level thinking skills.

2. Modeling adults. The kinds of problem-based learning are important to bridge the gap between formal school learning and mental activity more practical encountered outside the school.

3. Independent Learning (Self Directed Learning). In this lesson the students can decide for themselves what is to be learned, and from which the information was obtained with the guidance of teachers.

Problem-based Learning approach refers to the following matters:

1. Curriculum: PBL unlike the traditional curriculum since it requires a targeted strategy where project as the center.

2. Responsibility: PBL emphasizes responsibility and answerability learners to self and role model.

3. Realism; activities learners focused on work similar to the actual situation. This activity integrates authentic tasks and produce professional attitude.

4. Active- learning: raise the issues that led to the students' questions and a desire to find relevant answer, and thus there has been a self-learning process.

5. Feedback: discussion, presentation, and evaluation of learners generate valuable feedback.

6. General Skills; PBL was developed not only on the basic skills and knowledge, but also has a major impact on the fundamental skills such as problem solving, teamwork, and self-management.

7. Driving questions: PBL focused on questions or problems with the concepts, principles and knowledge accordingly.

8. Constructive investigations: the central point, the project should be tailored to the knowledge of the learners.

9. Autonomy: the project makes a very important activity. 


\section{METHOD}

\section{A. Types of Research}

This study is a research \& development (Research and development). The product that will be developed in this study is the English language textbook based on Problem Based Learning to class VII as the implementation of Curriculum 2013. Once the product is developed, it will be done analysis of the validity, enforceability observational analysis, students' activities, and the students' responses to learning activities.

\section{B. Development Procedure}

This study uses a study design development with 4-D model of development. Semmel states that the model development consists of four phases: define, design, develop and disseminate. Completely the procedures to be performed are as follows:

\section{Define phase.}

This phase aims at defining the terms of textbook-based problem-based valid in accordance with the curriculum of 2013. There are three activities that conducted the analysis of needs, analysis of students and analysis of syllabus.

\section{Design phase.}

The design phase is to design-based problem-based text books in accordance with the implementation of the curriculum in 2013 as seen from the aspect of design and organization, content language, topics and skills.

3. Develop phase.

This stage aims to produce any the fine text book, validation, the practicalities and effectiveness phase.

\section{Disseminate phase.}

This stage is the use of products that have been developed on a wider scale. In this case, the textbook will be used by seventh grade junior high school students in the city of Padang. In this phase, researchers will deploy a book that had been developed earlier to some schools are piloting a curriculum of 2013. And this is where researchers will gain insight into the effectiveness of the book.

\section{Research Instrument}

\section{Instrument Validation}

This instrument in the form of sheets of validity that is used to collect data on the validity of the English language text books based on problem based learning in accordance with the implementation of the curriculum in 2013.

\section{Sheet Practicalities}

This sheet is used to collect data practicality consisting of:

1. The observation sheet appropriateness of textbooks with curriculum 2013

2. The student questionnaire responses to textbooks

3. The questionnaire responses of teachers to textbooks.

\section{Sheets Effectiveness}

These instruments are used to collect data for effectiveness, this instrument consists of:

a. Sheet observation of student activity

This sheet is used to record student activity of students during the learning process.

b. Sheets learning outcomes

This sheet is used to obtain the data needed to determine the percentage of student success.

\section{Technique of Data Analysis}

Data obtained from the results of validation and the test will be analyzed by the each appropriate technique.

\section{a. Data Validation}

Data from the validation of the book obtained, analyzed based on aspects of textbooks are presented in tabular form using a Likert scale, then the average value by using the following formula:

$$
\begin{gathered}
\mathrm{R}=\Sigma \mathrm{nj}=1 \mathrm{Vij} \\
\mathrm{nm}
\end{gathered}
$$

With:

$\mathrm{R}$ : the average results of the assessment of the experts / practitioners

Vij : score assessment experts / practitioners all criteria j

$\mathrm{N}$ : number of experts / practitioners

$\mathrm{M}$ : number of criteria

The average obtained will be confirmed with the following criteria: when the average $>3.20$ then categorized as very valid, when $2.40<$ mean $<3.20$ then considered valid, when $1.60<$ mean $<2.40$ then considered less valid, when the average $<0,80$ then considered invalid (Muliyardi, 2006: 82).

\section{b. Analysis of the Practicalities}

1). Usability Analysis of Textbooks Result

Results usefulness of this text will be analyzed using qualitative descriptive statistics with the following conditions:

a) $(1.00$ to 1.99$)=1=$ bad $=$ incompatible, unclear, implemented, not operational

2) $(2.00$ to 2.99$)=2=$ poor $=$ compatible, obvious, implemented, not operational

3) $(3,00-3,49)=3=$ good $=$ correspond, obvious, done, less operational

4) $(3.50$ to 4.00$)=4=$ very good $=$ correspond, obviously, implemented, operational

2). Student Response Analysis

Student responses about the content of the textbook will be analyzed by using a percentage (\%), namely: $\mathrm{PRS}=\mathrm{f} \times 100 \%$

Where: $\mathrm{f}=$ frequency of students who answered, $\mathrm{s}=$ many students, student response RPS = percentage (Trianto, 2000: 83 ). Then linked with the categories Very Good if PRS = $81-100 \%$, Good if PRS $=61-80 \%$, Not Good if PRS $=21-$ $40 \%$, and Very Not Good if PRS $=1-20 \%$ (Riduwan, 2011: 89). 


\section{c. Analysis Effectiveness of Textbooks}

1. Analysis of student activity

Data from student activity sheets were analyzed by calculating the percentage. The formula used percentage proposed by Sudjana (1989: 355), namely:

Percentage $=$ frequency of student activities undertaken $\mathrm{X} 100 \%$ The number of students

The assessment criteria adopted and modified liveliness of Arikunto (1999). Criteria activity if $81-100 \%$ Very High, High if $61-80 \%$, if $41-60 \%$ Medium, Low if $21-40 \%$, and Very Low if $1-20 \%$

\section{RESULT AND FINDING}

This research has been done on February until June 2017. The researchers did this research on 4 steps. They are Define, Design, Develop and Disseminate for two years. On this research researchers only discuss about define and design step.

\section{A. Result Define}

To get a valid text book on this research, the researchers did define step. However, on this step the researchers analyzed about English text book which were used by the English teachers in teaching learning process on piloting schools. This analysis done to see whether the materials which are taught appropriate with hopefully competence. In this case, the book which used was "When English Rings the Bell” published by KEMENDIKBUD RI 2013.

There has the differences basic competence between basic competence on syllabus and English text book. They are on basic competence 3. On syllabus used understand but on English text book used identify. It means, on English text book is more details, explain about social function, structural text, language content on introducing expression, and respond based on the context used. However, the development was done on every activity on each chapters of the book. Students are asked to work on team and do the exercises and report them spoken and written.

The next step is need analysis. On this step, the researchers surveyed and interviewed English teachers who teach class VII and students class VII. Result analysis concluded that:

1. $95 \%$ teachers need materials problem based learning on English text book.

2. $100 \%$ teachers need English text book which the materials consist of the students' real daily context.

3. Materials which are used by English teachers has look like problem based learning.

Result of the questioners showed that $90 \%$ teachers need media to motivate their students in learning. However, teachers also used media likes card, video, real object and clock on teaching learning process. Most of teachers used those of media. Finally, teachers also suggested to state media on the English text book to ease teaching process.

\section{B. Result design}

Learning tool which is designed is English text book. This tool integrated problem based learning on learning English for Junior High School class VII which is focused on 8 themes. The themes are:

1. Good morning. How Are you?

2. It's Me

3. What Time Is it?

4. This is My World

5. It's a Beautiful Day!

6. We Love What We Do

7. I'm Proud of Indonesia

8. That's What Friends are Supposed to do

The development of English text book focused on problem based learning which is developed based on basic competence which is published by Kemendikbud RI. Those basic competences are:

\section{Good morning. How Are you?}

Basic competences used are:

1.1 Memahami fungsi sosial, struktur teks, dan unsur kebahasaan pada ungkapan sapaan, pamitan, ucapan terimakasih, dan permintaan maaf, serta responnya, sesuai dengan konteks penggunaannya.

1.1 Menyusun teks lisan sederhana untuk mengucapkan dan merespon sapaan, pamitan, ucapan terimakasih, dan permintaan maaf, dengan memperhatikan fungsi sosial, struktur teks, dan unsur kebahasaan yang benar dan sesuai konteks

\section{It's Me.}

Basic competences used are:

3.2 Memahami fungsi sosial, struktur teks, dan unsur kebahasaan pada ungkapan perkenalan diri, serta responnya, sesuai dengan konteks penggunaannya.

4.2 Menyusun teks lisan dan tulis sederhana untuk menyatakan, menanyakan, dan merespon perkenalan diri, dengan sangat pendek dan sederhana, dengan memperhatikan fungsi sosial, struktur teks, dan unsur kebahasaan yang benar dan sesuai konteks.

\section{What Time Is it?}

Basic competences used are: 3.3 Memahami fungsi sosial, struktur teks, dan unsur kebahasaan dari teks untuk menyatakan dan menanyakan nama hari, bulan, nama waktu dalam hari, waktu dalam bentuk angka, tanggal, dan tahun.

4.3 Menyusun teks lisan dan tulis untuk menyatakan dan menanyakan nama hari, bulan, nama waktu dalam hari, waktu dalam bentuk angka, tanggal, 
dan tahun, dengan unsur kebahasaan yang benar dan sesuai konteks.

\section{This is My World}

Basic competences used are:

3.4 Memahami fungsi sosial, struktur teks, dan unsur kebahasaan dari teks pemaparan jati diri, sesuai dengan konteks penggunaannya.

4.4 Menangkap makna pemaparan jati diri lisan dan tulis sangat pendek dan sederhana.

4.5 Menyusun teks lisan dan tulis untuk memaparkan dan menanyakan jati diri, dengan sangat pendek dan sederhana, dengan memperhatikan fungsi sosial, struktur teks, dan unsur kebahasaan yang benar dan sesuai konteks.

\section{It's a Beautiful Day}

Basic competences used are:

3.5 Memahami fungsi sosial, struktur teks, dan unsur kebahasaan pada teks untuk menyatakan dan menanyakan nama dan jumlah binatang, benda, dan bangunan publik yang dekat dengan kehidupan siswa sehari-hari.

4.6 Menyusun teks lisan dan tulis untuk menyatakan dan menanyakan nama binatang, benda, dan bangunan publik yang dekat dengan kehidupan siswa sehari-hari, dengan memperhatikan fungsi sosial, struktur teks, dan unsur

kebahasaan yang benar dan sesuai konteks.

\section{We Love What We Do}

Basic competences used are:

3.5. Memahami fungsi sosial, struktur teks, dan unsur kebahasaan dari teks label nama (label) dan daftar barang (list), sesuai dengan konteks penggunaannya

4.7 Menyusun teks tulis label nama (label) dan daftar barang (list), dengan memperhatikan fungsi sosial, struktur teks dan unsur kebahasaan yang benar dan sesuai konteks.

\section{I'm Proud of Indonesia}

Basic competences used are:

3.7 Memahami fungsi sosial, struktur teks, dan unsur kebahasaan pada teks untuk menyatakan dan menanyakan sifat orang, binatang, benda sesuai dengan konteks penggunaannya.

4.8 Menyusun teks lisan dan tulis untuk menyatakan dan menanyakan sifat orang, binatang, dan benda, dengan memperhatikan fungsi sosial, struktur teks dan unsur kebahasaan yang benar dan sesuai konteks.

\section{That's What Friends are Supposed to do}

Basic competences used are:

3.8 Memahami fungsi sosial, struktur teks, dan unsur kebahasaan pada teks untuk menyatakan dan menanyakan tingkah laku/tindakan/fungsi orang, binatang, benda, sesuai dengan konteks penggunaannya.

4.8 Menyusun teks lisan dan tulis untuk menyatakan dan menanyakan tingkah laku/tindakan/fungsi dari orang, binatang, dan benda, dengan unsur kebahasaan yang benar dan sesuai konteks.

\section{CONCLUSION}

Based on the research that has been done by the researchers on schools in Padang, especially on Piloting Schools as implementation of curriculum 2013. The findings showed that from students' and teachers' need analysis, the teachers and students need English textbook of Problem Based Learning for Junior High School class VII as the implementation of Curriculum 2013. However, there have differences competences between syllabus and on English text book. So far, on English text book developed eight themes for eight chapters.

\section{Acknowledgment}

Thanks to all English teachers and student who have participated on this research and also express the gratitude to the headmaster of SMPN 1 Padang, SMPN 8 Padang, SMP 31 Padang, SMP 12 Padang, SMP Nasional, and SMP SIMA Padang for supporting this research.

\section{References}

[1] Tomlinson, B. Material Development in Language teaching.Cambridge: Cambridge University Press, 2003.

[2] Harmer, Jeremy. How to Teach English. England: Cambridge University Press, 1998

[3] William, Davids.” Developing Criteria for Textbook Evaluation" .ELT Journal Volume 37/1.432-452. .2000

[4] Weddel, Kathleen Santopietro."How to choose Good ESL Textbook". ELT JournalVolume 21/7. 32-41, 2009.

[5] Brown, J. D. The Element of Second Language Curriculum. Boston: An International Thomson publishing Company, 1995.

[6] Cunningsworth, A. Choosing Your Coursebook. Oxford: Heineman, 1995 